\title{
DOI 10.26886/2414-634X.1(20)2018.2
}

UDC: $630 * 4: 630 * 17: 582.475 .4$

\section{ENTOMOLOGIZES FACTORY IN THE PROCESS OF SPREADING COMMON PINE ROOT SPONGE UNDER THE CONDITIONS OF SHIP TIMBER FORESTRY OF STATE ENTERPRISE "ZHYTOMYR FORESTRY"}

\section{B. Levchenko, Candidate of Agricultural Sciences}

\section{V. Shulga, Candidate of Agricultural Sciences}

\section{R. A. Zalewski, Candidate of Agricultural Sciences}

Zhytomyr Agro-technical College, Ukraine, Zhytomyr

The article studies the species varieties of forest insects in the centers of attack with determination of the tree stocking degree. The major insect species are represented by such samilies as bark beetlesipidae capricon betles - Cerambycidae. The artice considers the effect of insect on common pipe decaying in the location of pine fungus. It has been substantiated that the formalion of forest insect attack centers depend on the age of trees. Concentration of larger and lasser pine - shoot beetles dominates in the forest of 40 years of age. They intensify the effect of pine fungus with further weakening the trees. Following the results of investigation it has been determined that such insects as larger pine-shoot beetle lesser pine-shoot beetle, black pine Capricorn beetle, blue pine char $\mathrm{cool}$ beetle, Curkulio glandium are the synergist of Heterobasidion annosum finvader.

Key words: pocket root sponge, degree of attack,stem insects.

кандидат сільськогосподарських наук, доцент, Левченко В. Б., кандидат сільськогосподарських наук, доцент, Шульга І. В., кандидат сільськогосподарських наук, Залевський $P . A$. Ентомологічний фактор розповсюдження збудника кореневої губки сосни звичайної в 
умовах корабельного лісництва дп «Житомирське ЛГ»/ Житомирський агротехнічний коледж, Україна, Житомир

Обгрунтовано значення ентомологічного фрактора у розповсюдженні кореневої губки сосни звичайної, а також видового складу стовбурових шкідників в осередках Heterobasidion annosum 3 визначенням ступеня заселеності дерев. Основні види стовбурових шкідників представлені родинами: короїди - Ipidae, вусачі Cerambycidae, златки - Buprestidae, довгоносики - Culculionida).

Предметом роботи є збудник кореневої губки сосни звичайної в умовах Корабельного лісництва державного підприємства «Житомирське лісове господарство». Метою роботи $\epsilon$ вивчення впливу стовбурових шкідників на всихання сосни звичайної в осередках кореневої губки. Встановлено, що формування осередків стовбурових шкідників залежить від віку насаджень - осередки великого і малого соснового лубоїдів переважають в насадженнях до 40 років, що призводить до підсилення шкідливої дії кореневої губки. Основними методами проведення робіт $\epsilon$ фрітопатологічна експертиза соснових насаджень, а також проведення обстежень соснових деревостанів з визначенням характеру всихання 6 залежності від ступеня ураження як збудником кореневої губки сосни звичайної, так і розповсюдження збудника ентомологічним шляхом в соснових деревостанах.

За результатами роботи встановлено, що формування осередків стовбурових шкідників залежить від віку насаджень осередки великого і малого соснового лубоїдів переважають $в$ насадженнях до 40 років, призводячи до підсилення шкідливої дії кореневої губки і значного ослаблення насадження в подальшому. В результаті проведених досліджень було виявлено, що великий сосновий лубоїд, малий сосновий лубоїд, чорний сосновий вусач, синя 
соснова златка, соснова жерднякова смолівка є синергітами збудника Heterobasidion annosum.

Сфрерою застосування результатів $є$ лісогосподарські підприємства різних форм власності з метою збереження та захисту лісових насаджень від збудника кореневої губки в умовах зони Полісся України.

Висновки досліджень полягають в тому, що для повноцінного відновлення лісів, з лісогосподарської точки зору найбільш ефрективнішим вирішенням проблеми є проведення рубок догляду, тоді, коли приріст починає сповільнюватися, отже вдається зберегти максимальний приріст дерев що залишаються, а від реалізації заготовленої при рубках догляду деревини отримати прибуток не чекаючи, поки вони будуть знищені шкідниками. В перспективі $\epsilon$ сенс в подальших дослідженнях штучно створених насаджень які ще довгий час не зможуть функціонувати без систематичного і регулярного лісогосподарського та лісосанітарного догляду, причому слід чітко розуміти, що цьому повинен передувати досить тривалий період трансформації штучних лісових фітоценозів до природного стану. Тому важливим завданням лісівників в ДП „Житомирське ЛГ” у цьому напрямку $є$ підтримання стабільного фітосанітарного стану насаджень $і$ всебічна стимуляція природних саморегуляційних процесів в лісових екоценозах.

Ключові слова: осередки кореневої губки, ступінь ураження, стовбурові шкідники.

Вступ. В осередках кореневої губки на ослаблених деревах заселяється ряд ентомошкідників, видовий склад яких визначається віком деревних порід, повнотою насаджень, близькістю осередків 
стовбурових шкідників та екологічними чинниками. У ослаблених дерев зменшується тиск живиці, яка механічно і фрізіологічно захищає дерева від пошкодження стовбуровими шкідниками, спалахи розмноження яких відбуваються з нерегулярними інтервалами, але, як правило, типові для ослаблених деревостанів, що знаходяться в стані фрізіологічного стресу.

\section{Аналіз останніх досліджень і публікацій, в яких започатковано} розв'язання проблеми. Дослідження А. І. Воронцова (1988) показали, що основною причиною всихання сосни звичайної в осередках кореневої губки $€$ стовбурові шкідники: за відсутності останніх гине близько 25\% уражених губкою дерев, тоді як за наявності шкідників кількість дерев, що загинули складала 80\%. Процес всихання протікає дуже повільно і може бути інтенсифікований лише посухою. Б. І. Оніщенко і О. Г. Флайтер відзначають, що в осередках кореневої губки складаються сприятливі умови для розмноження як хвоєгризучих, так і стовбурових шкідників, кількість яких значно збільшується [3, с. 6-10]. За літературними джерелами, спори кореневої губки, що пройшли через травний тракт стовбурових шкідників, залишаються життєздатними [4, с. 9-12]. Враховуючи специфіку способу життя цих комах i їх здатність харчуватися спорами грибів, можна зробити висновок про участь їх в процесах перенесення інфекції кореневої губки.

Після поселення комах на деревах сосни звичайної відповідного фрізіологічного стану, ними починається посилене виділення феромонів, що різко збільшує привабливість цих дерева. Чим більше таких первинних комах, тим сильніше дія феромонів, що виділяються і швидше відбувається подальше заселення дерева шкідниками. Кожен осередок в своєму розвитку проходить декілька фаз. Зазвичай розрізняються їх між собою по співвідношенню дерев різних категорій 
ослабленості і стану популяцій стовбурових шкідників [1, с. 3-5]. Комахи заселяють і активніше розмножуються на деревах, що знаходяться в стані найбільшого фрізіологічного стресу, спричиненого абіотичними, антропічними і іншими чинниками $[1$, с. $4-5,5$, с. $31-33,7$, с. 8-10].

Трофрічний фактор є більш передбачуваним, має значення не для всіх хвороб як сіянців, так і зрілих деревостанів, менше змінюється у часі по роках і періодах щодо фраз розвитку хвороб деревних рослин, $€$ більш динамічним щодо зміни погодних умов. Саме кліматичні фрактори обумовлюють суттєву мінливість стану збудника хвороби, змінюють строки розвитку патогену та його шкодочинність.

Провідна роль погодних умов у виникненні епіфітотій визнається багатьма дослідниками [2, с. 4-8, 3, с. 6-12, 4, с. 9]. Особливе значення кліматичні фрактори мають у регулюванні ритму розвитку рослин і патогенів, що змінює час попадання або розвитку найбільш агресивних і небезпечних рас на найменш стійкі до них критичні періоди розвитку рослин. Від співвідношення у часі цих процесів та інтенсивності їх проходження залежить ступінь шкодочинності, розмір ураження та оптимальність рішень щодо строків і необхідності проведення заходів із лісозахисту. Ці надзвичайно важливі для тактики сучасного лісозахисту питання здатний вирішити фрітопатологічний прогноз. Він визначає час початку епіфрітотії на лісових рослинах, а також можливий темп їх проходження у конкретних екологічних умовах. Методи френологічного прогнозу є основними для визначення оптимальних строків проведення обстежень, винищувальних та інших заходів лісозахисту, що $є$ обов'язковою умовою цілеспрямованого інтегрованого систематичного захисту лісової рослинності.

Фенологічна інформація за обсягом та значенням займає провідне місце серед інших видів фрітосанітарної інфрормації. Моніторинг і прогнозування епіфітотій неможливі без показників розвитку збудника 
хвороби. Наукові лісогосподарські заклади України, служба лісозахисту та інші, тривалий час і щорічно, під час багатьох видів лісогосподарських робіт спеціально проводять спостереження та реєстрацію появи і проходження патологічного процесу розвитку фенофраз основних хвороб на лісових культурах. На цей час накопичено велику інформативну базу даних, яка потребує систематизації i аналізу для відповідних лісорослинних умов Житомирського Полісся.

Такі дослідники, як Б. В. Добровольський [5, с. 12, 6, с. 34 - 62], А. С. Подольський $[7$, с. 10] в свій час закладали наукові основи розвитку фенопрогнозу. Багаторічні фенологічні дані після відповідної статистичної обробки і аналізу можуть бути основою для переведення всіх робіт із лісозахисту за календарно-френологічним принципом.

Фенологічна інформація враховується під час розробки прогнозів, і вона $\epsilon$ особливо необхідна для короткострокових прогнозів і сигналізації. Методологія прогнозування ґрунтується на тісному зв'язку розвитку патогену збудника хвороби з умовами зовнішнього середовища. Реакція патогенів на зміну погодних умов обумовлена на генетичному рівні їх багатовіковою еволюцією у конкретних лісорослинних умовах природнокліматичних зон. Тому середні багаторічні строки проходження фенофраз еволюційно сформовані кліматом певної зони, а відхилення від них по роках залежать від ступеня відхилення від норми погодних умов конкретного року на попередніх етапах онтогенезу виду деревної породи.

В умовах Житомирського Полісся різниця по роках у строках розвитку фенофраз збудників може досягати 15-20 днів. На швидкість онтогенезу впливає сума фракторів погоди, але найбільш доцільно брати у ролі предиктора прогнозування показники сумарного 
ефрективного тепла, що накопичується з початку розвитку виду в конкретних умовах року.

Більш точний фенологічний прогноз можна отримати у першій половині вегетації для початкових фаз під час прояву патологічного процесу хвороб в лісових культурах або пристигаючих деревостанах. У другій половині літа і восени строки проходження патологічного процесу по роках змінюються не так помітно, а температурний режим цього періоду впливає в основному на підготовку до зимівлі.

Краще прогнозувати початок патологічного процесу тому, що визначення строків масового феноявища звичайно ускладнюється через коливання чисельності епіфітотій і патологічного стану в насадженнях по роках.

Територія України має в основному вирівняний рельєф і патологічні явища проходять одночасно на великих площах. Із запізнених або випереджених на один тиждень генерацій стовбурових шкідників у напрямку південь-північ відзначено розповсюдження дорослих комах на відстані 100-120 км, а в напрямку захід-схід - 200300 км. У Карпатах в залежності від висоти і експозиції схилу можуть бути значні відхилення. Цю закономірність слід використовувати у повсякденній роботі служби прогнозів служби «Укрлісозахист». Фенологічна інформація, яку отримують пункти сигналізації і прогнозів, що працюють у більш теплих природнокліматичних зонах України, повинна бути сигнальною для районів, де фенофази проходять пізніше.

Формулювання мети статті та завдань досліджень. Метою наших досліджень були особливості та перебіг ураження соснових деревостанів Житомирського Полісся, а також осередки збудника кореневої губки, осередки розповсюдження шкідників соснових насаджень в умовах зони Полісся України. Крім цього, досліджувались 
процеси, які проходять в лісових борових екосистемах, що в свою чергу лежать в основі ураження сосни звичайної кореневою губкою. Завданням досліджень було: проаналізувати вплив лісової ентомофауни на розповсюдження збудника кореневої губки сосни звичайної в умовах Житомирського Полісся, та надати практичні рекомендації щодо підвищення стійкості соснових насаджень в умовах Житомирського Полісся. Для проведення досліджень було обстежено осередки кореневої губки в чистих штучних насадженнях сосни звичайної в умовах Корабельного лісництва ДП „Житомирське ЛГ” у віці 40-80 років. Пробні площі закладено за загальноприйнятою методикою, на них здійснювали суцільний перелік дерев і фріксували їх стан за шкалою згідно з нормативним документом "Санітарні правила в лісах України" [8, р. 395-409.]. Характер розвитку осередків кореневої губки визначався біологічними особливостями збудників і умовами зовнішнього середовища, тому ураження часто носило осередковий характер. В осередках кореневої губки (ураженість насаджень становила від 21 до $60 \%$ відповідно) було виявлено комплекс стовбурових шкідників, представлений такими родинами і видами: родина короїдів Ipidae (великий сосновий лубоїд Blastophagus piniperda L., малий сосновий лубоїд Blastophagus minor Hart.); родина вусачі Cerambycidae (чорний сосновий вусач Monochamus galloprovincialis pistor OI.); родина златки Buprestidae (синя соснова златка Phaenops cyanea F.); родина довгоносики Culculionidae (соснова жерднякова смолівка Pissodes piniphillus Hbst.). Проведення обліків в умовах пробних площ здійснювали по прокладених маршрутах. Для проведення обліків використовували методику обстеження пробних площ лісових масивів. В процесі проведення фрітопатологічної експертизи особливу увагу звертали на виявлення основного та прихованого пошкодження насадження сосни звичайної основними 
шкідниками хвойних порід, зокрема: малим сосновим лубоїдом, великим сосновим лубоїдом, синьою златкою, сосновим жердняковим смолюхом, синім рогохвістом, чорним сосновим вусачем. Крім цього, ставилось завдання виявити вплив пошкодження насаджень сосни звичайної шкідниками соснових насаджень, а також підсилення ураження деревостанів збудником кореневої губки як синергетичного фактора взаємодії. Результати спостережень записувались в реєстраційний журнал проведення досліджень.

Виклад основного матеріалу статті. Найбільш поширеною родиною стовбурових шкідників у осередках кореневої губки є короїди Ipida. Вона представлена великим сосновим лубоїдом та малим сосновим лубоїдом. Формування осередків стовбурових шкідників залежить від віку насаджень - осередки великого і малого соснового лубоїдів переважають в насадженнях до 40 років, призводячи до підсилення шкідливої дії кореневої губки і значного ослаблення насадження в подальшому. Виліт імаго починається з першої декади липня. Молоді імаго додатково живляться в кронах здорових дерев, виїдаючи серцевину пагонів, спричиняючи їх опадання (так званий ефект «стрижка крони»). Родина рогохвостів, представлена синім рогохвостом Paururus juvencus L. Родина довгоносики представлена сосновою жердняковою смолівкою Pissodes piniphillus Hbst.) Вони були виявлені в середньовікових насадженнях. Чорний сосновий вусач Monochamus galloprovincialis pistor OI. - небезпечний, екологічно пластичний шкідник сосни, який заселяє ослаблені та звалені дерева, необкорені лісоматеріали у насадженнях жерднякового віку. Личинки синьої златки Phaenops cyanea F. пошкоджують дерева, починаючи 3 45-річного віку, прогризаючи під корою звивисті ходи, які спочатку ледь зачіпають заболонь, проте дуже часто після значного ослаблення дерева, спостерігається відпадання кори з оголенням деревини. 
Для виявлення видового складу та перспектив розмноження стовбурових шкідників у типових насадженнях був проведений аналіз модельних дерев. На стовбурах модельних дерев від основи до верхівки знімалася стрічка кори шириною 10 см. За кількістю маточних ходів стовбурових шкідників (на 1 дм $^{2}$ ) на знекореній стороні стовбура визначались райони та щільність їх поселення (таблиця 1).

Таблиця 1

\section{Заселення дерев стовбуровими шкідниками в умовах}

Корабельного лісництва ДП „Житомирське лг”

(середнє за 2015 - 2017 рр.)

\begin{tabular}{|c|c|c|c|c|c|c|c|c|c|c|c|c|}
\hline \multirow{3}{*}{$\begin{array}{c}\text { Вік } \\
\text { дерев }\end{array}$} & \multicolumn{12}{|c|}{ Види стовбурових шкідників, шт. } \\
\hline & \multicolumn{2}{|c|}{ 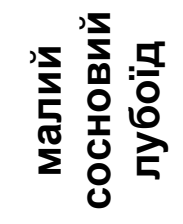 } & \multicolumn{2}{|c|}{ 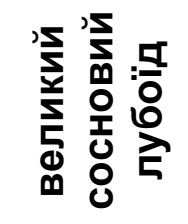 } & \multicolumn{2}{|c|}{ 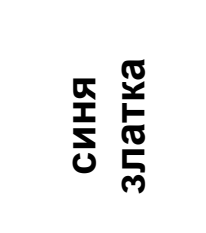 } & \multicolumn{2}{|c|}{ 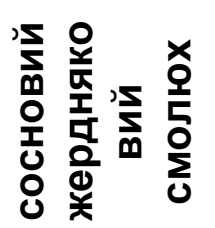 } & \multicolumn{2}{|c|}{ 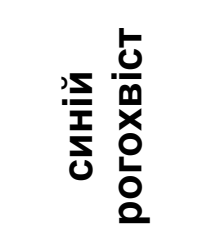 } & \multicolumn{2}{|c|}{ 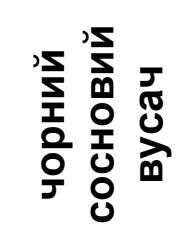 } \\
\hline & шт. & $\%$ & шт. & $\%$ & шт. & $\%$ & шт. & $\%$ & шт. & $\%$ & шт. & $\%$ \\
\hline До 45 & 6 & 3 & 5,2 & 3 & 0,4 & 2 & 0,4 & 2 & 0,4 & 2 & 0,2 & 2 \\
\hline $45-65$ & 8 & 4 & 2 & 2 & 0,5 & 4 & 0,7 & 5 & 0,6 & 3 & 0,6 & 3 \\
\hline $65-85$ & - & - & - & - & 0,8 & 5 & 0,5 & 3 & 0,9 & 5 & 0,4 & 2 \\
\hline $\mathrm{HIP}_{05}$ & 1,22 & - & 1,18 & - & 1,21 & - & 1,16 & - & 1,41 & & 1,25 & - \\
\hline
\end{tabular}

Аналіз отриманих результатів вказує на те, що осередки стовбурових шкідників характеризуються середнім і низьким ступенем заселення дерев. Відомо, що для хронічних осередків, характерні тривалий період існування, порівняно невисокі, хоча і підвищені (порівняно із здоровими насадженнями), рівень чисельності комах і розмір поточного відпаду (рис. 1). 


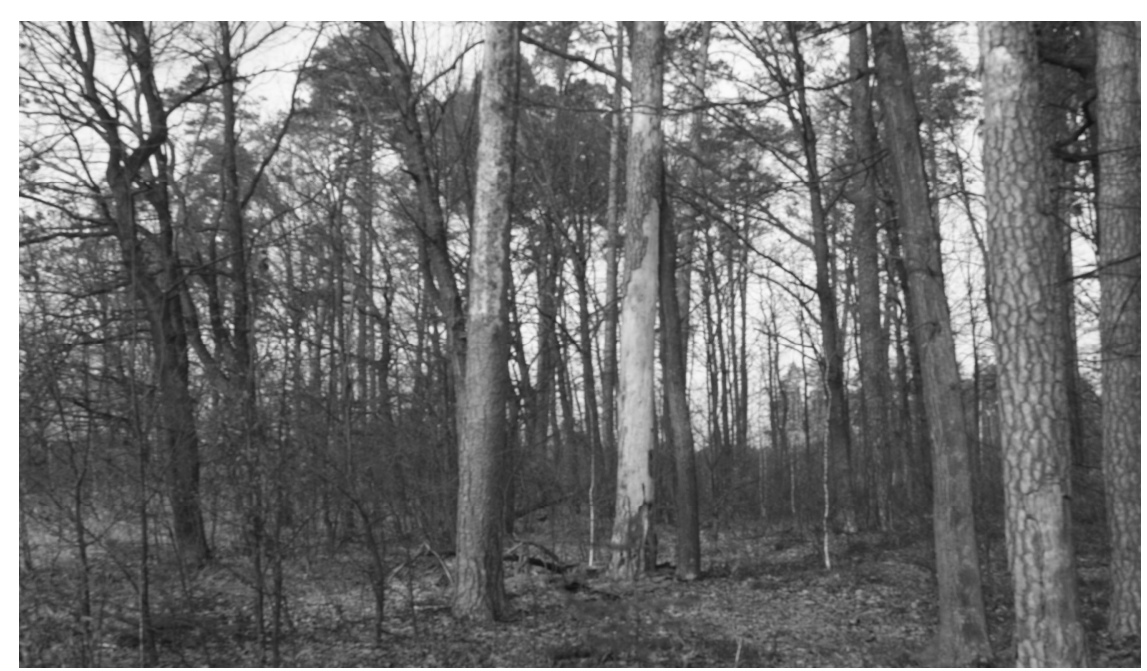

Рис. 1. Насадження, уражене Чорним сосновим вусачем Monochamus galloprovincialis pistor $\mathrm{Ol}$.

У обох випадках можливі оборотні і необоротні реакції насаджень, хоча в другому при масових розмноженнях найчастіше відбувається повне руйнування насадження. Поблизу від вогнищ масового розмноження, що характеризуються надмірною щільністю популяції, зазвичай виникають міграційні осередки, куди розселяються комахи у пошуках нових місць розселення. Ці осередки діють протягом декількох років, поки відбуваються остаточне розсіювання популяції і повернення іiї до початкового рівня чисельності в даному районі (рис. 2, 3).

Ступінь пошкодження дерев комахами, незважаючи на триразову обробку крон інсектицидами, була значною і відрізнялася як в розрізі клонових особин, так і за строками проведення. Так, пошкоджень комахами під час проведення обстежень 20 червня 2017 року виявлено не було. Серед вибірки, взятої наприкінці липня, 38 обстежених пробних площ сосни звичайної, жодна не була пошкоджена, а в решти частини насаджень частка пошкоджених деревостанів становила від 10 (пробна площа 12) до 45,5\% (пробна площа 3). Наприкінці серпня пошкодження сосновим лубоїдом виявлені в насадженях усіх обстежених пробних площ, а частка пошкоджених деревостанів 
становила від 10\% (пробна площа П - 35, П - 33) до 69,2 \% (пробна площа П-20).

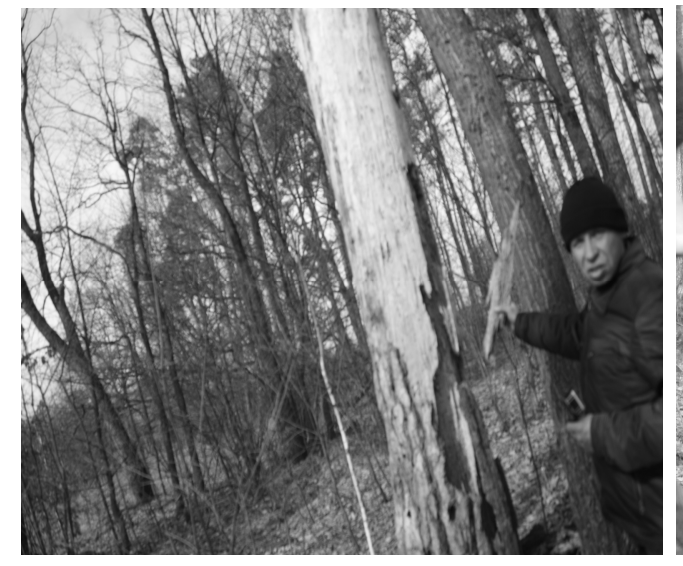

Рис. 2. Насадження, знищене великим сосновим лубоїдом

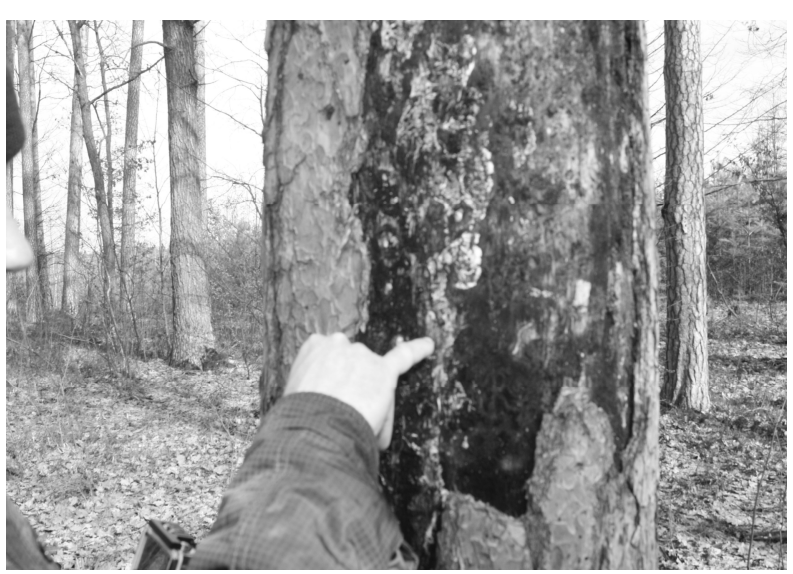

Рис. 3. Личинка великого соснового лубоїда під корою

При проведенні аналізу стиглих деревостанів у вересні місяці виявилося, що соснові насадження у 12,5\% зразків пробної площі П-24 повністю були пошкоджені imago соснового лубоїда та короїда. Серед насаджень пробної площі П-20, ступінь ураження становив 33,3\% були здорові на вигляд дерева, проте всередині під корою було виявлено личинки і ступінь ураження пробних площ становила 26,7\%, а повністю пошкоджені личинками стовбури дерев складали 15 \%. У насаджень пробної площі П-36 личинки виявлено в 36,7\% дерев, а 25\% дерев були повністю уражені личинками короїда. Серед деревостанів пробної площі П-35 у 60\% виявлено личинки соснового лубоїда. Деревостан пробної площі П-31 містив 25\% здорових дерев 27,5\% стовбурів були уражені личинкою великого соснового лубоїда і 26,7 \% повністю нею пошкоджені. Пробна площа П-26 мала 50\% здорових дерев, 45\% були пошкоджені личинкою великого соснового лубїда, а 20 \% - повністю знищені. Частка деревостану пробної площі П-33, що містили личинки короїда становила 35 \%, а 45 \% були ними пошкоджені. Серед усіх пробних площ найбільше пошкоджені личинками великого соснового лубоїда була пробна площа П-26 (45\%), хоча майже всі дерева були 
зовнішньо здоровими (рис. 4.). Деревостан пробної площі П-33 був на 45\% пошкоджений личинками чорного соснового вусача.

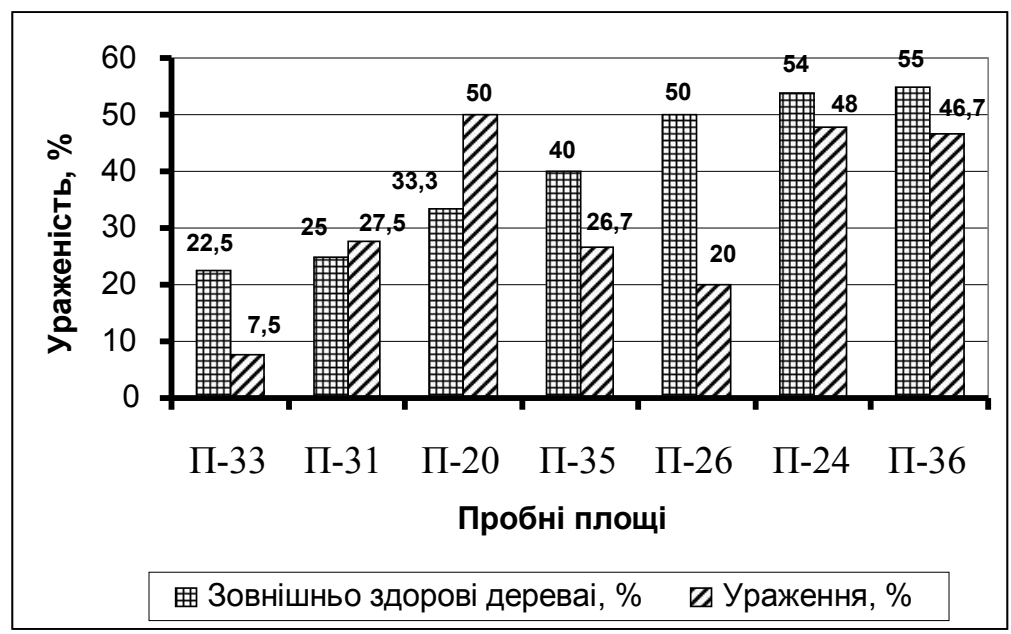

Рис. 4. Оцінка насаджень сосни звичайної за резистентністю до збудника кореневої губки в умовах ДП «Житомирське ЛГ»

Як видно з вище сказаного, стан насадження відрізнявся за пробними площами і частка зовнішньо здорових дерев становила від 22,5\% (пробна площа П-33) до 55\% (пробна площа П-36).

Найменша ураженість деревостану шкідниками становила 7,5\% у пробної площі П-33, яка характеризувалась найменшою часткою уражених дерев. Найвищу ураженість виявлено у деревостанів пробної площі П-20 (із середньою часткою зовнішньо здорових дерев), П-24 і П36 (із високою часткою зовнішньо здорових дерев). В процесі досліджень була визначена ураженість збудником кореневої губки для всієї сукупності деревостанів сосни звичайної в розрізі всіх пробних площ. Середня ураженість дерев в розрізі основних пробних площ становила $32,3 \%$, а середня частка зовнішньо здорових дерев складала $42,4 \%$.

Частка здорових на вигляд дерев пробної площі П-24 в середньому становила 54 \%. Вона перевищувала фрітомоніторингову ураженість в 2015 році, яка становила 48\%. Це свідчить, що зовні здорові дерева з наявністю личинок малого соснового лубоїда, 
великого соснового лубоїда, соснової златки, чорного соснового вусача в середньому були уражені на $34,5 \%$ і являли собою осередки розповсюдження як шкідників, так і збудника кореневої губки сосни звичайної, внаслідок чого з часом це призвело до масового всихання насаджень. У пробної площі П-20 при фітопатологічному моніторингу була виявлена ураженість насадження в межах 16,7\%, що перевищила частку зовні здорових дерв, тобто інфрекція знаходилась в латентному стані.

Склад агресивних штамів збудника кореневої губки сосни звичайної, виявлених на ураженик деревах різних пробних площ сосни звичайної, також відрізнявся. Так серед штамів виявлених на пробних площах П-35 і П-36 переважали збудники $H$. annosum в дуже агресивному вигляді, так як їх патогенні раси не реагували 3 сивороткою, а також було виявлено зооспори збудника альтернарії, та на пробній площі П-20 - монілії.

Під час проходження мікологічного аналізу в зовнішньо здорових деревостанах сосни звичайної виявлено збудникі хвороб іншого таксономічного походження, при чому в 22,5\%, їх виявлено одночасно декількох збудників: Penicillium, - 43,8\% зразків, Alternaria - 32,6\%, Mисor - 16,3\%. Fusarium, Trichotecium уражували 8,8 \%, Trichoderma i Rhizopu по $5 \%$, Aspergillus - 2,5\%.

При мікологічному аналізі деревини, які зовнішньо не мали ознак пошкодження у 40,6 \% виявлено личинки соснового лубоїда або соснового короїда. При цьому було уражено 35,6\% - альтернарією, 5\% - фрузаріумом, 48,8\% - пеніцилліумом, 12,5\% - мукором, 9,4\% трихотецієм, 3,8\% - триходермою, 5,6\% - ризопусом, 6,9\% тамнідіумом, причому майже в половини деревостанів сосни звичайної виявлено водночас декількох збудників. 
У насіннин, зібраних із плюсових дерев сосни звичайної, які мали зовнішньоздорові ознаки, було виявлено личинки довгоносика $(29,2 \%)$, при мікологічному аналізі виявлено альтернарію $(31,4 \%)$, пеніциліум (50\%), мукор (20\%), трихотецій (10\%), триходерму (2,9\%), ризопус $(7,1 \%)$, при чому в $21,4 \%$ насіння сосни звичайної виявлено водночас декількох патогенних збудників. Таким чином можна сказати, що шкідники соснових насаджень $€$ воротами інфекції та синергітами збудника кореневої губки сосни звичайної в умовах Корабельного лісництва ДП «Жиомирське ЛГ».

Висновки та перспективи подальших розвідок у цьому напрямку.

1. Насадження у віці від 45 до 65 років фрормують епізодичні осередки, які $€$ найбільш небезпечними. Дані насадження характеризуються високим ступенем ослаблення від кореневої губки 41 - 60\%, та належать до затухаючих вогнищ кореневої губки.

2. Комахи-шкідники здатні регулювати середній приріст рослин аж до максимального рівня для конкретних умов зростання, проте цей природний процес часто вступає в суперечність з короткостроковими лісогосподарськими цілями людини.

3. Пошкодження шкідниками за часом нерідко наближається до того періоду, коли ліс досягає максимальної щільності біомаси або коли живий деревостан має найбільший запас.

4. Щоб використовувати деревину, яка може бути в подальшому уражена шкідниками, потрібно вирубувати дерева на початку їх ураження.

5. 3 лісогосподарської точки зору, найбільш ефективнішим вирішенням проблеми є проведення рубок догляду тоді, коли приріст починає сповільнюватися, отже вдається зберегти максимальний приріст дерев, що залишаються, а від реалізації заготовленої при 
рубках догляду деревини отримати прибуток не чекаючи, поки вони будуть знищені шкідниками.

6. Перспективи подальших досліджень полягають у вивченні штучно створених насаджень які ще довгий час не зможуть функціонувати без систематичного і регулярного лісогосподарського та лісосанітарного догляду, причому слід чітко розуміти, що цьому повинен передувати досить тривалий період трансформації штучних фітоценозів до природного стану. Тому важливим завданням лісівників в ДП „Житомирське ЛГ” у цьому напрямку є підтримання стабільного фітосанітарного стану насаджень і всебічна стимуляція природних саморегуляційних процесів в лісових екоценозах.

\section{תimepamypa:}

1. Анищенко Б. И. Защита хвойных насаждений от корневых гнилей. - Минск, 2001 - C. 4-5.

2. Берриман А. М. Защита леса от насекомых-вредителей. - М.: „Агропромиздат”, 1990. - 288 с.

3. Василяускас A. П. Экология и биология корневой губки (Fomitopsis annosa (Fr) Karst) и фракторы, ограничивающие ее патогенность в хвойних насаждениях Литовской ССР: авторефр. дис. на соиск. ученой степени доктора биол. наук. - Тарту, 1981. - 20 с.

4. Воронцов А. И. Лесозащита. - М.: „Агропромздат”, 2008. - 335с.

5. Воронцов А. И. Корневая губка. - Харьков. 2004. - С. 31-33.

6. Воронцов А. И. Технология защиты леса. - М.: „Агропромздат”, 1991. -304 c.

7. Санітарні правила в лісах України. - К.: МЛГ України, 1995. - 20 с.

8. Asiegbu F., Adomas A., Stenlid J. Conifer root and butt rot caused by Heterobasidion annosum (Fr.) Bref. // Department of Forest Mycology \& Pathology, Swedish University of Agricultural Sciences [Тексm. 
Електронний ресурс]. / Asiegbu F., Adomas A., Stenlid J. // Molecular Plant Pathology.- P. 395 - 409.

\section{References:}

1. Anischenko B. I. Saschita hvoinih nasagdeniy ot kornevih gniley. Minsk, - 2001. - s. 4 - 5.

2. Berriman A. M. Sachita lesa ot nasikomih vrediteley. - M.: "Agropromisdat", 1990. - $228 \mathrm{~s}$.

3. Vasilyuskas A. P. Ekologiya I biologiya kornevoy gubky (Fomitopsis annosa (Fr) Karst) $i$ factor,i ogranichuuschie ee patogennost $v$ hvoynih nasagdeniyah Litivskoy SSR: avtoref. dis. na soisk. Uchennoy stepeni doktora boil. nauk. - Tartu, 1981. - 20 s.

4. Voronzov A. I. Lesozaschita. - M.: "Agropromisdat", 2008. - 335 s.

5. Voronzov A. I. Kornevaja gubka. - Harkov. 2004. - s. 31 - 33.

6. Voronzov A. I. Tehnologiya saschiti lesa. - M.: "Agropromisdat", 1991. $304 \mathrm{~s}$.

7. Sanitarni pravila v leash Ukraini. - K.: MLG Ukrainy, 1995. - 20 s.

8. Asiegbu F., Adomas A., Stenlid J. Conifer root and butt rot caused by Heterobasidion annosum (Fr.) Bref. // Department of Forest Mycology \& Pathology, Swedish University of Agricultural Sciences [Тексm. Електронний ресурс]. / Asiegbu F., Adomas A., Stenlid J. // Molecular Plant Pathology. - P. 395 - 409. 